\title{
Application of the Case Based Reasoning (CBR) Method to Diagnose Conjunctivitis
}

\author{
Tri Erviyanti ${ }^{1)}$, Volvo Sihombing ${ }^{2) *}$, Gomal Juni Yanris ${ }^{3)}$ \\ 1) 2) ${ }^{3}$ Labuhan Batu University, Indonesia \\ ${ }^{1)}$ volvolumbantoruan@gmail.com, ${ }^{2}$ silaengomal@yahoo.com
}

Submit: Mar 16, 2021 | Accepted: Apr 27, 2021 | Published: Nov 23, 2021

\begin{abstract}
Conjunctivitis is an inflammation of the conjunctiva or the outer layer of the eye and the inner lining of the eyelids caused by micro-organisms or viruses, bacteria, fungi, chlamydia, allergies, irritation of chemicals. The problems that arise start from common symptoms that are often shown or are shown by eye diseases such as redness of the eye area and then cause pain and soreness. Diagnosis can be made by an ophthalmologist. In addition, to diagnose eye diseases, an expert system can also be used to pour expert knowledge into an expert system, thus helping diagnose eye diseases. The research objective is to analyze a desktop-based expert system program that contains the knowledge of a trusted expert / doctor who has the ability to be able to diagnose the disease from the eye disease symptoms felt by the patient quickly and precisely. The stages of research carried out in this study include literature study, data collection, system design, system creation, In addition to testing the system, the authors developed a Case Based Reasoning (CBR) method, which is a method to build an expert system by making decisions from new cases with solutions from previous cases to determine the type of conjunctivitis. The results of the research obtained in the study for the diagnosis of conjunctivitis were the values of old cases and new cases which obtained high similarity weight values, namely 0.94 and 0.69 .
\end{abstract}

Keywords: Case Based Reasoning, Diagnosis, Expert System, Conjunctivitis, Application

\section{INTRODUCTION}

The eyes are the five senses that are very important in human life, so eyes should be part of the body that need to be maintained in everyday life(Ilyas \& Yulianti, 2017). Complaints about eye disorders are considered commonplace in everyday life and consider these complaints to disappear on their own. The problem that often arises is that there are still few experts or experts on conjunctivitis in dealing with patients who are consulted for the disease, thus researchers make an expert system research that can replace an expert by looking at the expert system that has been designed, so that people who need it do not. neglected by the system.

According to (Aji et al., 2018)explained that an expert system is a knowledge-based system, which is defined as a computer application that has the goal of helping decision making or solving in certain fields. Research(Ananta Dama Putra et al., 2018) Eye disease or conjunctivitis is inflammation of conjunctivitis or the outer layer of the eye and the inner lining of the eyelids caused by micro-organisms or viruses, bacteria, fungi, chlamydia, allergies, irritation of chemicals.

The purpose of this research is to help control conjunctivitis (pink eye) infectious diseases using the Case Based Reasoning (CBR) method, which is a method to build an expert system by making decisions from new cases with solutions from previous cases.(Minarni., Indra, W., \& Wenda, H, 2017). The basic idea of CBR mimics human abilities, namely solving new problems using answers or experiences from old problems.(Shinta et al., 2017)Knowledge representation is made in the form of cases. Each case contains problems and answers, thus comparing new cases with a certain pattern containing knowledge from an expert / doctor who is believed to be correct who has the ability to be able to diagnose a disease from symptoms -the eye symptoms felt by the patient quickly and precisely. 


\section{CBR method}

\section{LITERATURE REVIEW}

According to (Heroes \& Wibisono, 2017)Mendiefenisikan that CBR is one of the problem-solving methods which in the calculation process produces a solution to the case being analyzed into a new case. The CBR process will conduct a search process for solutions to cases handled with problems that have been experienced before.(Sari Murni, 2019)

In research (Putri et al., 2016) explained that CBR has a 4-stage process that is used in solving problems.

1. Retrieve

2. Reuse

3. Revise

4. Retain

Of the four processes above, it involves specific steps in solving problems using the CBR method.

The results of the research conducted (Minarni., Indra, W., \& Wenda, H, 2017) that the CBR method has the formula:

Information :

$$
\text { Similarity }(p, q)(1)=\frac{\mathrm{S} 1 * \mathrm{~W} 1+\mathrm{S} 2 * \mathrm{~W} 2+\cdots+\mathrm{Sn} * \mathrm{Wn}}{\mathrm{W} 1+\mathrm{W} 2+\cdots+\mathrm{Wn}}
$$

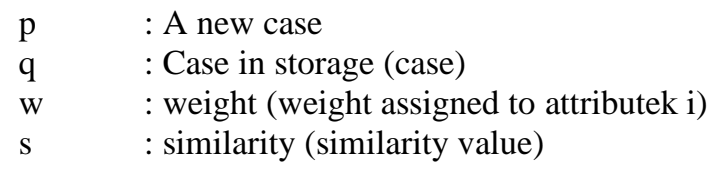

\section{Expert system}

Expert systems are defined as well(Ramadan \& Pane, 2018) Knowledge Based System, which is defined as a computer application that has the goal of helping decision making or solving in a particular field(Gunawan \& Wardoyo, 2018). According to(Sinaga et al., 2018) that the benefits of an expert system are:

1. Expert systems can work faster than humans.

2. The quality level of suggestions is very consistent and can reduce problems.

3. Capturing human expertise

4. Make it easier for expert knowledge

5. Can be used to support the training of a test.

\section{METHOD}

The stages of the research method used in conducting research consist of five stages including:

1. Literature study, is the initial stage in carrying out research with the aim of formulating problems by means of observations.

2. Data collection, the steps taken to collect the data needed to be used in testing with the method used, besides that, the data collection stages are carried out by reading references in the form of scientific journals or e-books as the reference language in supporting research that is will be done. The data obtained were 3 diseases and 20 symptoms.

3. System Design, this stage designs or designs a system with Visual Basic applications with Microsoft Access databases in accordance with the kebuthan of the problem.

4. System Creation

This stage creates a system that has been designed according to the requirements needed in the CBR method for diagnosing conjunctivitis with visual basic.

5. System Testing

Test the system by inputting the symptoms experienced in accordance with the selected symptoms provided in the application. 


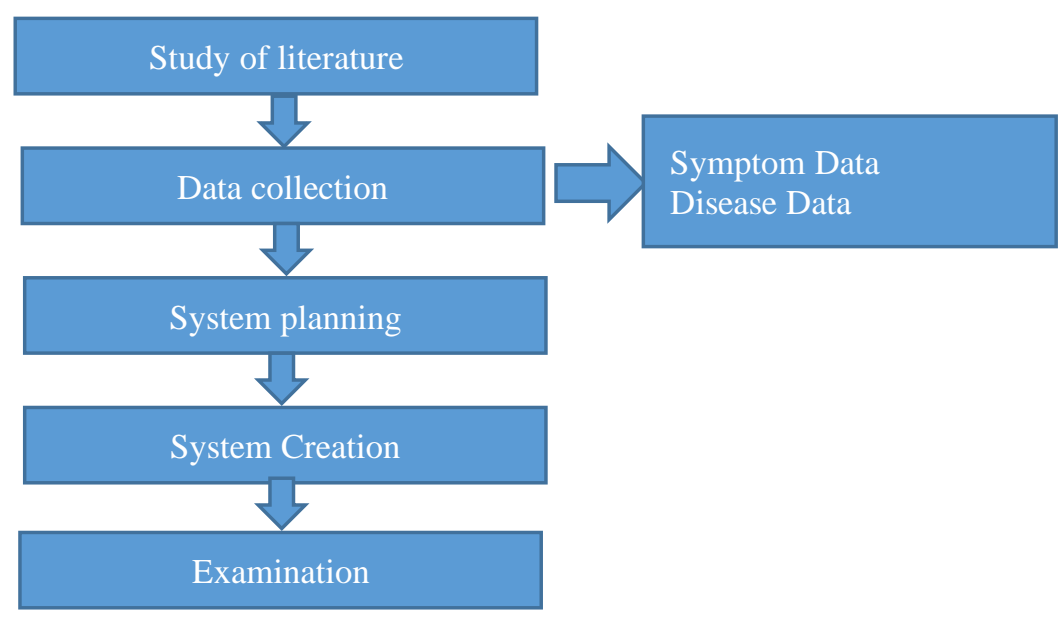

Figure 1. Research Stages

\section{RESULTS}

To calculate the CBR method, the first steps taken provide symptom data and disease data that will be used in the calculation, it can be seen in the following table (Salamun, 2018):

After obtaining the symptom and disease data, the next step is to determine the weight value in the knowledge base with the provisions as shown in table 1 . The user enters the symptoms experienced at the beginning of the process by matching one by one to the symptoms in the knowledge base. With the following conditions:

Weight Parameters (w)

Significant Symptoms $=5$

Moderate symptoms $=3$

Usual Symptoms $=1$

$$
\begin{aligned}
& \text { Disease Case Rate: } \\
& \text { Infective }=0-0.25 \\
& \text { Irritation }=0.26-0.50 \\
& \text { Allergy }=0.51-0.1
\end{aligned}
$$

Table 1. Symptom Data

\begin{tabular}{clc}
\hline \multirow{2}{*}{ CODE } & \multicolumn{1}{c}{ SYMPTOMS } & WEIGH \\
& & T \\
\hline G01 & Itchy eyes & 5 \\
G02 & Pain or burning in the eye & 5 \\
G03 & Watery eyes & 3 \\
G04 & Difficulty opening your eyes when you wake up & 1 \\
G05 & Swollen eyelids & 5 \\
G06 & Blurred vision & 5 \\
G07 & Feeling twitching or something in the eye & 3 \\
G08 & More sensitive to light & 3 \\
G09 & Fever & 5 \\
G10 & Eye pain & 5 \\
G11 & A scab forms on the eyelids when you wake up in the morning. & 3 \\
G12 & The lashes stick together & 3 \\
G13 & Disturbed Vision & 1 \\
G14 & One or both eyes are very red & 5 \\
G15 & Enlarged lymph nodes in front of the ear. & 3 \\
G16 & Eyes feel like gritty. & 5 \\
G17 & The eyelids sting & 1 \\
G18 & Small spot inside the eyelid & 5 \\
G19 & Runny Nose & 3 \\
G20 & Sneeze Sneeze & 1 \\
\hline
\end{tabular}

For disease data(Zulfikar \& Lukman, 2016) can be seen in the table below: 
Table 2. Disease Data

\begin{tabular}{cc}
\hline \hline CODE & DISEASE \\
\hline P01 & Infective Conjunctivist \\
P02 & Irritation Conjunctivist \\
P03 & Conjunctivist Allergy \\
\hline
\end{tabular}

CBR method One application of an expert system that can analyze handling or solutions to problems with conjunctivitis is to use the case-base reasoning method, which is an artificial intelligence approach and emphasizes problem solving based on knowledge or experience from old cases and previous events that have existed or occurred.(Eclipse et al., 2017).

As a case of calculation using the CBR method as follows:

Table 3. Old Cases

\section{Old Case K01}

\begin{tabular}{|c|c|c|}
\hline Symptoms: & Diseases: & Solution: \\
\hline $\begin{array}{l}\text { 1. Lymph nodes that are enlarged in front } \\
\text { of the ear } \\
\text { 2. Eyes feel like burning } \\
\text { 3. Watery eyes }\end{array}$ & $\begin{array}{l}\text { Conjunctivitis } \\
\text { effective }\end{array}$ & $\begin{array}{l}\text { 1. Use tear drops which are useful as a lubricant to } \\
\text { relieve pain and stickiness in the eyes. This drug } \\
\text { can be purchased over the counter at a pharmacy. }\end{array}$ \\
\hline $\begin{array}{l}\text { 4. Eyes feel like gritty. } \\
5 \text {. Sensitive to light. }\end{array}$ & & $\begin{array}{l}\text { 2. Wash hands regularly after touching the infected } \\
\text { eye so that it is not contagious. }\end{array}$ \\
\hline
\end{tabular}

Old Case K02

\section{Symptoms:}

1. Itching in the eyes

2. Feeling twitching or something in the eye

3 . One or both eyes are very red

4. Eye pain

5. The lids are sore

\section{Diseases:}

Irritation

Conjunctivist

\section{Solution:}

1. Compress the eyes with a cloth dampened in cold water.

2. Avoid exposure to allergens.

3. Do not wear contact lenses until the symptoms of conjunctivitis disappear.

4. To prevent symptoms from worsening, do not rub your eyes even if they feel itchy.

\section{Old Case K03}

1. Watery eyes

2. Swollen eyelids

3. A scab forms on the eyelids when you wake up in the morning.

4. Difficulty opening your eyes when you wake up

5. Impaired Vision
1. Antihistamines either in the form of eye drops or oral medicines. The purpose of this drug is to relieve allergy symptoms.

Allergic

conjunctivitis
2. Mast cell stabilizers are useful in controlling allergy symptoms for a long period of time.

Table 4. New Cases

Case 1 New Case

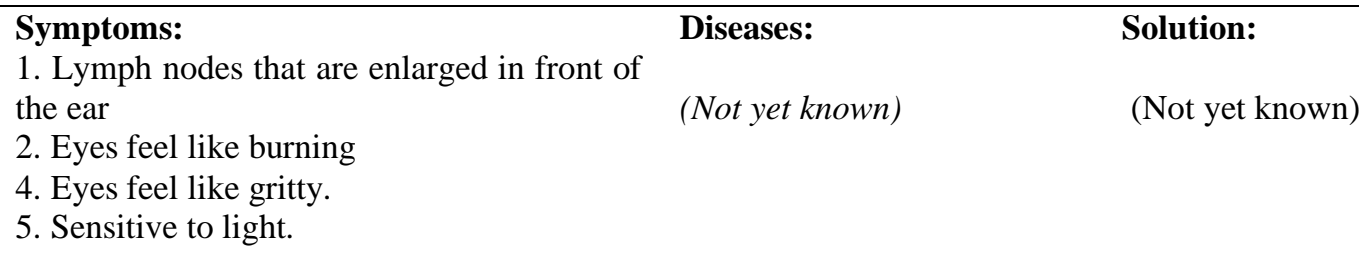

New Case 


\section{Symptoms:}

1. Eyes Feels Itchy

2. Runny Nose

3. Sneezing

4. The eyelids sting

5. There is something in the eye

\section{Symptoms:}

1. Red Eyes

2. Small spot inside the eyelid

3. Fever

4. Impaired eyesight

\section{Diseases:}

(Not yet known)

New Case

Cause:

(Not yet known)

Solution:

(Not yet known)

From the data above, a comparison between the old case and the new case is obtained as follows:

Table 5. Comparison Value of New Cases and Old Cases

\begin{tabular}{|c|c|c|c|}
\hline New Case I & Weight & " Old Case K01 & $\begin{array}{l}\text { Weigh } \\
\text { t }\end{array}$ \\
\hline Symptoms & & Symptoms: & \\
\hline $\begin{array}{l}\text { 1. Lymph nodes that are enlarged in front } \\
\text { of the ear }\end{array}$ & 3 & $\begin{array}{l}\text { 1. Lymph nodes that are enlarged in front } \\
\text { of the ear }\end{array}$ & 3 \\
\hline 2. Eyes feel like burning & 5 & 2. Eyes feel like burning & 5 \\
\hline 3. Difficult to open your eyes when you & 1 & 3. Watery eyes & 3 \\
\hline wake up & 5 & 4. Eyes feel like gritty. & 5 \\
\hline $\begin{array}{l}\text { 4. Eyes feel like gritty. } \\
\text { 5. Sensitive to light. }\end{array}$ & 3 & 5. Sensitive to light. & 3 \\
\hline New Case II & & Old Case K02 & \\
\hline 1. Eyes Feels Itchy & 5 & Symptoms: & \\
\hline 2. Runny Nose & 3 & 1. Itching in the eyes & 5 \\
\hline 3. Sneezing & 1 & 2. Feeling twisted or something is up on & 3 \\
\hline 4. The eyelids sting & 1 & eye & \\
\hline \multirow[t]{4}{*}{ 5. There is something in the eye } & 3 & 3. One or both eyes are very red & 5 \\
\hline & & 4. Eye pain & 3 \\
\hline & & 5. The lids are sore & \\
\hline & & & 3 \\
\hline Case III & & Old Case K03 & \\
\hline 1. Eyes Feels Itchy & 5 & 1. Watery eyes & 3 \\
\hline 2. Runny Nose & 5 & 2. Swollen eyelids & 5 \\
\hline 3. Sneezing & 5 & 3. A scab forms on the eyelids when you & 3 \\
\hline 4. The eyelids sting & 1 & wake up in the morning. & \\
\hline \multirow[t]{3}{*}{ 5. There is something in the eye } & 1 & 4. Difficulty opening your eyes when you & 1 \\
\hline & & wake up & 1 \\
\hline & & 5. Impaired Vision & \\
\hline
\end{tabular}

Based on the old case and the new case from the table above Similarity (the same symptom) to the old case K01 with new case 1 , the similariry value can be calculated as follows:

Similarity New Cases 1.

Similarity $(x, y)=\frac{\mathrm{S} 1 * \mathrm{~W} 1+\mathrm{S} 2 * \mathrm{~W} 2+\cdots+\mathrm{Sn} * \mathrm{Wn}}{\mathrm{W} 1+\mathrm{W} 2+\cdots+\mathrm{Wn}}$

Similarity $(\mathrm{x}, \mathrm{y})=(1.3)+(1.5)+(0.1)+(1.5)+(1.3) / 3+5+1+5+3$

Similarity $(\mathrm{x}, \mathrm{y})=3+5+0+5+3 / 17$ 
$\operatorname{Similarity}(\mathrm{x}, \mathrm{y})=\frac{16}{17}$

Similarity $(\mathrm{x}, \mathrm{y})=0.94$

Similarity New Case 2:

Similarity $(x, y)=\frac{\mathrm{S} 1 * \mathrm{~W} 1+\mathrm{S} 2 * \mathrm{~W} 2+\cdots+\mathrm{Sn} * \mathrm{Wn}}{\mathrm{W} 1+\mathrm{W} 2+\cdots+\mathrm{Wn}}$

Similarity $(\mathrm{x}, \mathrm{y})=(1.5)+(1.3)+(0.1)+(1.1)+(0.3) / 5+3+1+1+3$

Similarity $(\mathrm{x}, \mathrm{y})=5+3+0+1+0 / 13$

Similarity $(\mathrm{x}, \mathrm{y})=\frac{9}{13}$

Similarity $(\mathrm{x}, \mathrm{y})=0.69$

\section{Similarity New Cases 3}

Similarity $(x, y)=\frac{\mathrm{S} 1 * \mathrm{~W} 1+\mathrm{S} 2 * \mathrm{~W} 2+\cdots+\mathrm{Sn} * \mathrm{Wn}}{\mathrm{W} 1+\mathrm{W} 2+\cdots+\mathrm{Wn}}$

Similarity $(\mathrm{x}, \mathrm{y})=(0.5)+(0.5)+(0.5)+(1.1)+(1.1) / 5+5+5+1+1$

Similarity $(\mathrm{x}, \mathrm{y})=0+0+0+1+1 / 13$

Similarity $(\mathrm{x}, \mathrm{y})=\frac{2}{17}$

$\operatorname{Similarity}(\mathrm{x}, \mathrm{y})=0.11$

Calculation of cases 1,2 and 3 is the calculation of the retrieve process based on the weight of the symptoms that appear, if the symptom of a new case is the same as the symptom of an old case, then $1 \mathrm{x}$ the weight of the parameter, otherwise if the symptom of a new case is different from the symptom of an old case then $0 \mathrm{x}$ is the weight of the parameter.

a. Reuse Analysis

From the above calculations, the case that has the lowest weight is case 3 which is equal to 0.11 . Case 1 and Case 2 produce high similarity weights, namely 0.94 and 0.69 . In the reuse process, the solution given is the solution with the highest similarity weight to the old case and the new case, in this case, the K01 case, namely Effective Conjunctivist.

b. Revise Analysis

The process of revising is a process of reviewing cases and solutions provided if the system retrieves the results of not being able to provide an accurate diagnosis. In this example, the K01 case has produced a solution with a level of confidence above $80 \%$, so the resulting solution can be immediately given.

But if it turns out that after the calculation process has been carried out and there are no similar cases with the new case, then a revise process is carried out. Information in the form of symptom input on new cases that have no resemblance to the case database will be accommodated in a special table (revise table) which will then be evaluated and revised by experts to find the right solution.

\section{c. Retain Analysis}

After the revise process is complete and the correct solution has been found, then the expert starts adding rules by entering new case data whose solution has been found into the case database which can later be used for subsequent cases that have the same problem. This process is known as retain.

\section{DISCUSSION}

From the above calculations, the case that has the lowest weight is case 3 which is equal to 0.11 . Case 1 and Case 2 produce high similarity weights, namely 0.94 and 0.69 . In the reuse process, the solution given is the solution with the highest similarity weight to the old case and the new case, in this case, the K01 case, namely Effective Conjunctivist. the results of the research carried out are the results of an expert system which is an initial diagnosis and further diagnosis is needed by a doctor.

* Volvo Sihombing 


\section{CONCLUSION}

With the Expert System to Help Control Conjunctivitis Infectious Diseases, users can immediately check or diagnose themselves with the application system that has been made. The expert system created helps ophthalmologists in providing treatment to their patients without having to forget what medication or advice should be given to the patient because the system has stored all the ophthalmologist's knowledge into the computer.

\section{REFERENCES}

Aji, A. H., Furqon, M. T., \& Widodo, A. W. (2018). Sistem Pakar Diagnosa Penyakit Ibu Hamil Menggunakan Metode Certainty Factor ( CF ). Jurnal Pengembangan Teknologi Informasi Dan Ilmu Komputer, 2(5), 2127-2134. http://j-ptiik.ub.ac.id/index.php/j-ptiik/article/view/1556

Ananta Dama Putra, P., Adi Purnawan, I. K., \& Purnami Singgih Putri, D. (2018). Sistem Pakar Diagnosa Penyakit Mata dengan Fuzzy Logic dan Naïve Bayes. Jurnal Ilmiah Merpati (Menara Penelitian Akademika Teknologi Informasi). https://doi.org/10.24843/jim.2018.v06.i01.p04

Gerhana, Y. A., Irfan, M., \& Slamet, C. (2017). IMPLEMENTASI TECHNOLOGY ACCEPTANCE MODEL UNTUK MENGUKUR PENERIMAAN GURU TERHADAP INOVASI PEMBELAJARAN (Studi Kasus Model Pembelajaran CBR Di SMK). Jurnal Teknik Informatika.

Gunawan, E. P., \& Wardoyo, R. (2018). An Expert System Using Certainty Factor for Determining Insomnia Acupoint. IJCCS (Indonesian Journal of Computing and Cybernetics Systems), 12(2), 119. https://doi.org/10.22146/ijccs.26328

Ilyas, S., \& Yulianti, S. R. (2017). Ilmu Penyakit Mata. In Badan Penerbit Fakultas Kedokteran Universitas Indonesia.

Minarni., Indra, W., \& Wenda, H, . (2017). Case-Based Reasoning (CBR) pada Sistem Pakar Identifikasi Hama dan Penyakit Tanaman Singkong dalam Usaha Meningkatkan Produktivitas Tanaman Pangan. Jurnal TEKNOIF.

Pahlawan, arno reza, \& Wibisono, S. (2017). IMPLEMENTASI CASE BASED REASONING UNTUK SISTEM DIAGNOSIS HAMA DAN PENYAKIT TANAMAN CABE MERAH MENGGUNAKAN ALGORITMA SIMILARITAS NEYMAN. SINTAK.

Putri, T. E., Andreswari, D., \& Efendi, R. (2016). Implementasi Metode CBR (Case Based Reasoning) dalam Pemilihan Pestisida terhadap Hama Padi Sawah Menggunakan Algoritma K-Nearest Neighbor (KNN) (Studi Kasus Kabupaten Seluma). Jurnal Rekursif.

Ramadhan, P. S., \& Pane, U. F. S. (2018). Analisis Perbandingan Metode (Certainty Factor, Dempster Shafer dan Teorema Bayes) untuk Mendiagnosa Penyakit Inflamasi Dermatitis Imun pada Anak. Jurnal SAINTIKOM (Jurnal Sains Manajemen Informatika Dan Komputer).

Salamun, S. (2018). Penerapan Algoritma Nearest Neighbor dan CBR pada Expert System Penyimpangan Perilaku Seksual. Jurnal Online Informatika. https://doi.org/10.15575/join.v2i2.97

Sari Murni, F. R. (2019). Penerapan Metode Teorema Bayes Pada Sistem Pakar Untuk Mendiagnosa Penyakit Lambung.pdf (pp. 166-172).

Shinta, N. L. P., Kushartomo, W., \& Varian, M. (2017). PENGARUH NILAI CBR TANAH DASAR DAN MUTU BETON TERHADAP TEBAL PELAT PERKERASAN KAKU METODE BINA MARGA. Jurnal Muara Sains, Teknologi, Kedokteran Dan Ilmu Kesehatan. https://doi.org/10.24912/jmstkik.v1i1.436

Sinaga, B., Hasugian, P. M., \& Manurung, A. M. (2018). Sistem Pakar Mendiagnosa Kerusakan Smartphone. 3(1), 333-339.

Zulfikar, W. B., \& Lukman, N. (2016). PERBANDINGAN NAIVE BAYES CLASSIFIER DENGAN NEAREST NEIGHBOR UNTUK IDENTIFIKASI PENYAKIT MATA. Jurnal Online Informatika. https://doi.org/10.15575/join.v1i2.33 